UDC 615.322.28:615.076

N. M. Vorobets*, H. V. YAVORSKA**

*Danylo Halytsky Lviv National Medical University

**Ivan Franko National University of Lviv

\title{
MODIFICATIONS OF AGAR DIFFUSION METHOD TO DETERMINATION OF THE ANTIMICROBIAL EFFECT OF THE HERBAL MEDICINAL PRODUCTS
}

In this paper we analyzed the antimicrobial action of various herbal medicinal products of agar diffusion method in different versions: cylinders, cup plates, and paper discs. It has been found that, depending on the modification of the method used, the obtained results were different. All pharmaceutical products used by us were effective. A significant effect of the studied herbal medicinal products in test cultures of microorganisms was in the case of agar diffusion method in modifications of cylinders and of cup plates. Much less or negligible effect we observed in the case of modification of the method of paper discs.

Key words: antimicrobial activity; agar diffusion method modifications; antimicrobial effectiveness of herbal medicinal products

\section{INTRODUCTION}

At present it is known that less than $1 \%$ of bacteria can invade human organism and make it ill. There is also a strong evidence that microbes may contribute to many non-infectious chronic diseases such as some forms of cancer and coronary heart disease. Different diseases are caused by different types of microorganisms, and some of them can be treated by plants [4]. Worldwide spending on finding new anti-infective agents is expected. So, it is important to choose adequate methods for investigation of new antimicrobial herbal medicinal products (HMP), herbal preparations, and herbal substances.

Among extracts from plants used in liquid and solid forms are tinctures, teas, decoctions, cold infusions (macerates), juices, oils. These herbal preparations for medicinal administration contain various types of bioactive compounds, some of them are colored, others - discolored. Ukraine Official medicine uses plants' tinctures and semisolid dosage forms with antimicrobial properties, such as marigold (Calendula officinalis), sage (Salvia officinalis), sophora (Sophora japonica), eucalyptus (Eucaliptus globulus). Their purpose and method of usage are mainly stated in leaflet of these drug products but types of micro-organisms on which they have influence, are rarely indicated and there is no method by which antimicrobial activity of an extract was investigated. Literature review indicates that the antimicrobial properties of plant extracts are determined by using different methods. In the most cases this is the disc or agar well diffusion as-

(c) Vorobets N. M., Yavorska H. V., 2016 say [8] in various modifications. Although there are several versions of this method, it is unknown how much each of them is informative. In recent decades, a growing demands for antimicrobials of plant origin, therefore necessary to use adequate methods to determine their effectiveness. Various modifications of agar diffusion method have been used to install the informativeness of them in relation to antibacterial activity of HMP produced in Ukraine, on some test cultures (strains) of microorganisms.

\section{MATERIALS AND METHODS}

Antimicrobial activity studies were performed using samples of HMP that made in various pharmaceutical manufactures of Ukraine [2]:

Tinctura Calendulae: No. 1 (LLC DCT "Pharmaceutical Factory", Zhytomyr city); No. 2 (Pharmaceutical factory "Viola" Zaporizhzhya city);

Tinctura Eucalypti: No. 1 (LLC “Ternopharm” Ternopil' city), No. 2 LLC DCT "Pharmaceutical Factory", Zhytomyr city);

Tinctura Salviae: No. 1 (LLC DCT "Pharmaceutical Factory" Zhitomir city), No. 2 (LLC DCT "Pharmaceutical Factory" Zhitomir city);

Tinctura Sophorae Japonicae: No. 1 (Pharmaceutical Factory "Viola" Zaporizhzhya city);

Chlorophyllipt: No. 1 (JSC “Galichfarm” Lviv city), No. 2 (LLC "DZ” HNTSA Kharkiv city), No. 3 (JSC "Galichfarm” Lviv city).

Microorganisms were obtained from the culture collections of the Department of Microbiology of Ivan Franko Lviv National University. Organisms were as follows bacteria: 


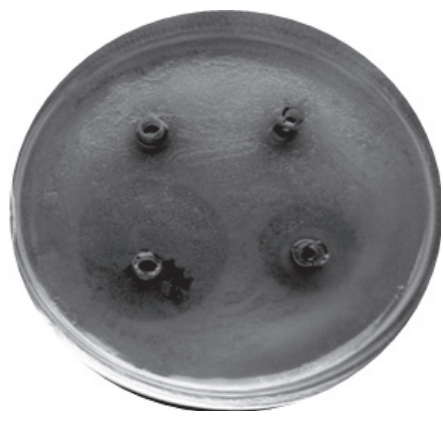

Fig. 1. Method of cylinders.

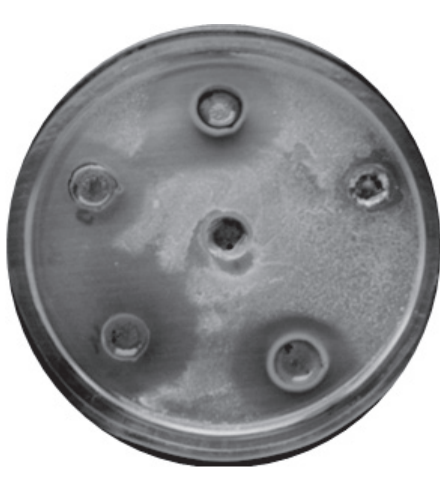

Fig. 2. Method of cup plates.

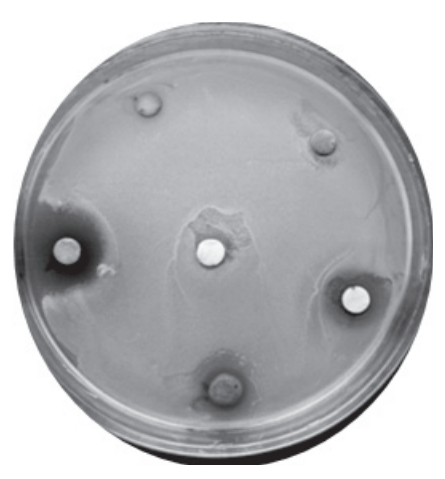

Fig. 3. Method of paper discs.

Escherichia coli B-4-E, Proteus vulgaris B-26-Pr, Serratia marcescens B-23-S, Bacillus subtilis B-10-B, Staphylococcus albus B-16-St, Staphylococcus aureus B-17-St, (including tree oxacillin resistent $S$. aureus strains), yeasts: Candida pseudotropicalis Y-209, Candida kefir Y-701.

We used bacterial cultures that are aerobic, and chemoorganotrophic, so they were grown in a stationary condition in a thermostat at $30 \pm 2{ }^{\circ} \mathrm{C}$ : bacteria grown on meat peptone agar and yeast - the wort-agar. The concentration of the cultures was to $10^{8}$ colony forming units. Culture medium adjusted to $\mathrm{pH} 7$ by $33 \% \mathrm{NaOH}$ solution, and sterilized at 0,5-0,7 atm within 20-30 minutes. Cultures of microorganisms stored in tubes with an appropriate medium at a temperature of $4-6{ }^{\circ} \mathrm{C}$. To determine antibiotic activity of herbal medicinal products used universally agar diffusion method in the modification of the glass cylinders (diameter 5-6 mm, height 8-10 mm); cup plates (diameter 5-6 $\mathrm{mm}$ ), and paper discs (fresh saturated) (diameter 5-6 mm) [7]. All work performed under aseptic conditions. We used a two-day culture of microorganisms which produced a suspension. The suspension of microorganisms containing approximately $10^{8}-10^{9} \mathrm{CFU} / \mathrm{ml}$ were made in sterile tap water, seeded lawn in a Petri dish for the culture medium $[1,5]$. One hour later sterile cylinders were arranged by using sterile tweezers (Fig. 1), and the cup plates were made (Fig. 2). Each cylinder and cup plate was filled by relevant extracts on $0.1 \mathrm{ml}$.

Also on the dotted paper discs arranged environment rich HMP (this standard sterile filter paper discs dripped slowly $0.1 \mathrm{ml}$, dried and saturated disks impose the culture of microorganisms) (Fig. 3). These Petri dishes were placed in the thermostat for 20-24 hours at a temperature of $30 \pm 2{ }^{\circ} \mathrm{C}$. The extraction solvents (as described in leaflet) were used as the negative control samples.

The diameters of the inhibition zones were measured in millimeters, and compared with those of the control and standard susceptibility disks. When the strain failed to show activity, the value considered was equal to zero. Bioassay was carried out in duplicate and later experiments were repeated twice.

A process for validation is essential in the generation of reliable and defensible results. The size of the inhibition zone is usually related to the level of antimicrobial activity present in the sample or product - a larger zone of inhibition usually means that the antimicrobial is more potent. To determine the antimicrobial activity of the samples of HMP a scale as Panchak L. et al. (2007) [6]: diameter zone growth delay of more than $20 \mathrm{~mm}-$ highly sensitive; 11-20 mm - sensitive was applied. Values ranging from 6 to $8 \mathrm{~mm}$ were considered as non-active against microorganisms.

The obtained values were subjected to statistical calculation using the Student test [3].

\section{RESULTS AND DISCUSSION}

Ten samples of HMP were screened for their antibacterial and antifungal activities. All pharmaceutical products used by us will be required to be effective. Despite these demands, accurate and credible results are needed because the interpretation of such results might have a serious impact on the course or focus of the further investigation and development of new pharmaceutical products. To clarify which of the modifications of agar diffusion method is the best suited to evaluate antibiotic properties of herbal medicinal products; the compared results were presented in Tab. 1.

As can be seen from this table HMP, depending on the method versions used, showed different effects on test bacterial cultures. Comparison of zones of growth inhibition shows that the largest ones were in the case of agar diffusion method in modification with cylinders, but the smallest - in paper discs modification. Commonly, the highest antibiotic activity had been shown for Tinctura Eucalypti, less - for Tinctura Salviae, Tinctura Sophore 


\section{ANTIMICROBIAL ACTION OF HERBAL MEDICINAL PRODUCTS}

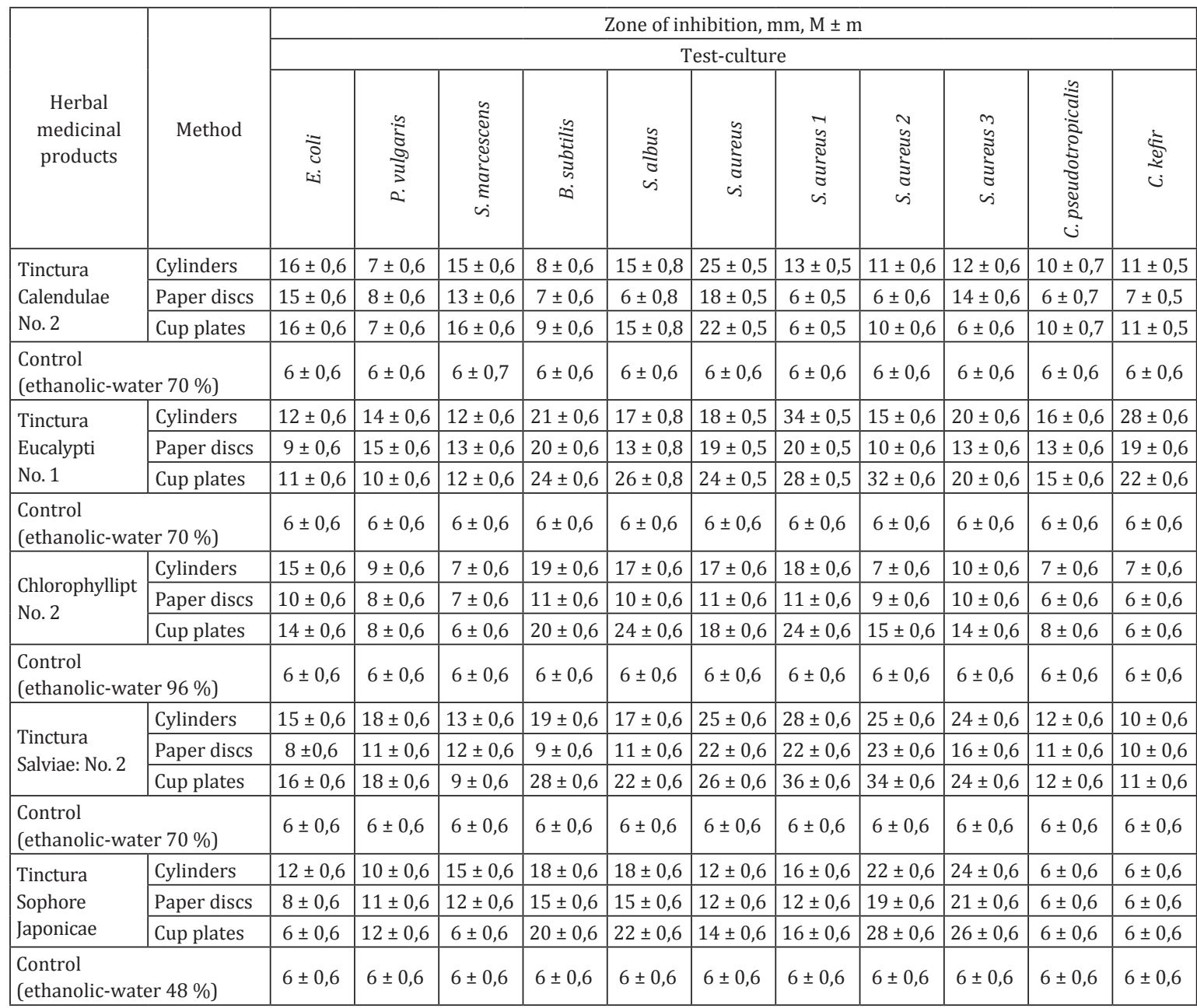

Japonicae, Tinctura Calendulae, and Chlorophyllipt. Tinctura Eucalypti delayed the growth of all investigated test cultures of microorganisms. Apparently sensitivity to the herbal medicinal product depends on its chemical composition and determined therein available antimicrobial components. But depending on the applied method modification, zones of inhibition ranged from large, (indicating a high sensitivity of microorganisms) to those that showed lower sensitivity. In general, high sensitivity to Eucalyptus tincture was established by a method of cylinders for three cultures; by cup plate method - in six; other cultures, regardless of the method used modifications were susceptible (zone stunted growth differ within $9-20 \mathrm{~mm}$ ).

The high sensitivity of Tinctura Salviae have been installed due the method of cylinders (4 investigated cultures), method of cup plates ( 6 studied cultures), and paper discs ( 3 cultures).

Analysis of the results for Tinctura Sophore Japonicae shows that the agar diffusion method to modify the cylinders revealed the high sensitivity of 2 cultures, method of cup plate -6 , paper discs -3 cultures.
Only one of the studied cultures proved to be highly sensitive to Calendula tincture when using methods of cylinders and cup plates, the remaining cultures were either sensitive or non-sensitive.

The high sensitivity of three cultures on chlorophyllipt was shown only by cup plate method, the results obtained using the methods of cylinders and discs of paper indicated that the majority of cultures are non-sensitive. The relatively low antimicrobial activity of chlorophyllipt is probably due to the fact that we have not investigated its effects on bacteria Staphylococcus which are the most sensitive to it.

Thus, our results indicate that the agar diffusion method in modification of cylinders is the most suitable to evaluate antibiotic properties of the herbal medicinal products.

In the following experiment we used the method of cylinders in order to compare the antimicrobial activity of just the same HMP, but from different manufacturers. The obtained results of the antibacterial and antifungal activities of them are presented in Tab. 2. While comparing two samples of tinctures of calendula, it has been 
Table 2

\section{COMPARISON OF THE ANTIMICROBIAL EFFECTS OF HERBAL MEDICINAL PRODUCTS FROM VARIOUS} PHARMACEUTICAL MANUFACTURES OF UKRAINE

\begin{tabular}{|c|c|c|c|c|c|c|c|c|c|c|c|c|}
\hline \multirow[b]{3}{*}{$\begin{array}{l}\text { Herbal medicinal } \\
\text { products }\end{array}$} & \multirow[b]{3}{*}{ 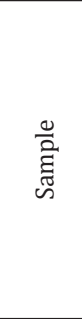 } & \multicolumn{11}{|c|}{ Zone of inhibition, $\mathrm{mm}, \mathrm{M} \pm \mathrm{m}$} \\
\hline & & \multicolumn{11}{|c|}{ Test-culture } \\
\hline & & $\begin{array}{l}: \overline{0} \\
\dot{0} \\
\dot{j}\end{array}$ & 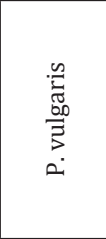 & 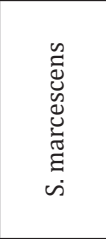 & 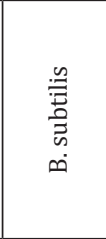 & $\begin{array}{l}\stackrel{0}{\Xi} \\
\stackrel{0}{\pi} \\
\dot{\omega}\end{array}$ & 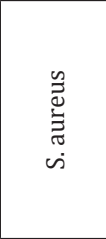 & 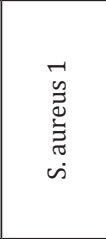 & 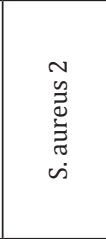 & 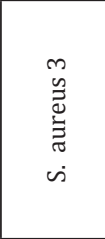 & 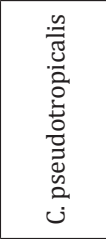 & 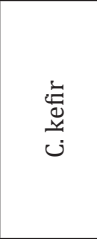 \\
\hline \multirow{2}{*}{$\begin{array}{l}\text { Tinctura } \\
\text { Calendulae }\end{array}$} & No. 1 & $15 \pm 0,6$ & $6 \pm 0,6$ & $16 \pm 0,6$ & $7 \pm 0,6$ & $12 \pm 0,6$ & $28 \pm 0,6$ & $13 \pm 0,6$ & $15 \pm 0,6$ & $16 \pm 0,6$ & $11 \pm 0,6$ & $12 \pm 0,6$ \\
\hline & No. 2 & $16 \pm 0,6$ & $7 \pm 0,6$ & $15 \pm 0,6$ & $8 \pm 0,6$ & $15 \pm 0,6$ & $25 \pm 0,6$ & $13 \pm 0,6$ & $11 \pm 0,6$ & $12 \pm 0,6$ & $10 \pm 0,6$ & $11 \pm 0,6$ \\
\hline \multirow{2}{*}{$\begin{array}{l}\text { Tinctura } \\
\text { Eucalypti }\end{array}$} & No. 1 & $12 \pm 0,6$ & $14 \pm 0,6$ & $12 \pm 0,6$ & $21 \pm 0,6$ & $17 \pm 0,6$ & $18 \pm 0,6$ & $34 \pm 0,6$ & $15 \pm 0,6$ & $20 \pm 0,6$ & $16 \pm 0,6$ & $28 \pm 0,6$ \\
\hline & No. 2 & $13 \pm 0,6$ & $14 \pm 0,6$ & $12 \pm 0,6$ & $22 \pm 0,6$ & $27 \pm 0,6$ & $18 \pm 0,6$ & $40 \pm 0,6$ & $23 \pm 0,6$ & $20 \pm 0,6$ & $16 \pm 0,6$ & $26 \pm 0,6$ \\
\hline \multirow{2}{*}{ Tinctura Salviae } & No. 1 & $16 \pm 0,6$ & $18 \pm 0,6$ & $12 \pm 0,6$ & $28 \pm 0,6$ & $18 \pm 0,6$ & $26 \pm 0,6$ & $26 \pm 0,6$ & $25 \pm 0,6$ & $22 \pm 0,6$ & $12 \pm 0,6$ & $11 \pm 0,6$ \\
\hline & No. 2 & $15 \pm 0,6$ & $18 \pm 0,6$ & $13 \pm 0,6$ & $19 \pm 0,6$ & $17 \pm 0,6$ & $25 \pm 0,6$ & $28 \pm 0,6$ & $25 \pm 0,6$ & $24 \pm 0,6$ & $12 \pm 0,6$ & $10 \pm 0,6$ \\
\hline
\end{tabular}

found that some cultures possessed a higher antimicrobial activity (strain number 1 of $S$. aureus). Eucalyptus tincture from different manufacturers also demonstrate a little different antibiotic effect on two test cultures of microorganisms (S.albus and S.aureus 2), but the difference was not significant. Sensitive to chlorophyllipt (regardless of extractant) were: E. coli, B. subtilis, S. albus, S. aureus. Regarding the impact of sage tincture, the samples tested inhibited the growth of all studied test strains. The biggest area of growth delay was observed in $B$. subtilis - $28 \mathrm{~mm}$, strains of $S$. aureus of range from 18 to $34 \mathrm{~mm}$.

Of all investigated tinctures growth of yeast cultures the most affected by eucalyptus tincture, calendula and sage were somewhat less, and others fail to demonstrate substantial influence.

\section{CONCLUSIONS}

From the results, it was concluded that universally agar diffusion method in the modification of the glass cylinders, cup plates, and paper discs can be used for investigation of antibiotic activity of herbal medicinal products. Among three compared modifications of agar diffusion method the most suitable one to evaluate their antibiotic properties was the modification of cylinders. Itallows makes possible to show sensitivity of microorganisms to the action of studied herbal medicinal products and probably plant extracts in a wide range. It is therefore recommended that the antibacterial properties of herbal medicinal products and plant extracts should be studied in detail by at least two modifications of method.

\section{REFERENCES}

1. Волянський Ю. Л. Вивчення специфічної активності антимікробних лікарських засобів: [метод. рекоменд.] / [Ю. Л. Волянський, І. С. Гриценко, В. П. Широбоков та ін.]. - К., 2004. - 38 с.

2. Державна фармакопея України / Державне підприємство «Науково-експертний фармакопейний центр». - 1-е вид. - Х.: РІРЕГ, 2001. - 556 с. Доп. 1. Х.: РІРЕГ, 2004. - 520 с. Доп. 2. - Х.: РІРЕГ, 2008. - 608 с.

3. Деркач М. П., Гумецький Р. Я., Чабан М. Є. Курс варіаційної статистики. - Л.: Вид-во Львівського університету, 1997. - 207 с.

4. Калиниченко Н. Ф. Определение активности антибактериальных средств наружного применения для лечения гнойно-воспалительных инфекций: [метод. рекоменд.] / Н. Ф. Калиниченко. - Х., 1991. - 16 с.

5. Методичні вказівки «Визначення чутливості мікроорганізмів до антибактеріальних препаратів». Наказ МОЗ України № 167 від 05.04.2007. - К., 2007. Код доступу: http://ua-info.biz/legal/baselw/uaqmwjae/index.htm

6. Панчак Л. В. Використання кореня хрону для одержання пероксидази та ефірної олії в одному технологічному циклі / Л. В. Панчак, М. М. Леб'як, Т. Г. Калинюк, В. О. Антонюк // Фармац. журн. 2007. - № 1. - С. 93-97.

7. Collins C. H. Collins and Lyne's Microbiological methods / C. H. Collins, P. M. Lyne, J. Grange. - London: Butterworth-Heinemam, 1995. - 456 p.

8. Cowan M. M. Plant products as antimicrobial agents / M. M. Cowan // Clin. Microbial Rev. - 1999. - Vol. 12, № 4. - P. 564-582. 


\section{УДК 615.322.28:615.076}

Н. М. Воробець, Г. В. Яворська

МОДИФІКАЦІЯ МЕТОДУ ДИФУЗІЇ В АГАР ДЛЯ ВИЗНАЧЕННЯ АНТИМІКРОБНОЇ ДІЇ ПРЕПАРАТІВ РОСЛИННОГО ПОХОДЖЕННЯ

Шляхом експериментального мікробіологічного дослідження обгрунтовано доцільність використання різних модифікацій методу дифузії в агар (циліндриків, лунок та дисків) для оцінки антимікробної активності лікарських препаратів рослинного походження.

Ключові слова: антимікробна активність; модифікації методу дифузії в агар; антимікробна активність лікарських препаратів рослинного походження

\section{УДК 615.322.28:615.076}

\section{Н. Н. Воробец, Г. В. Яворская}

МОДИФИКАЦИЯ МЕТОДА ДИФФУЗИИ В АГАР ДЛЯ ОПРЕДЕЛЕНИЯ АНТИМИКРОБНОГО ДЕЙСТВИЯ ПРЕПАРАТОВ РАСТИТЕЛЬНОГО ПРОИСХОЖДЕНИЯ

Путем экспериментального микробиологического исследования обосновано целесообразность использования различных модификаций метода диффузии в агар (цилиндриков, лунок и дисков) при оценке антимикробной активности лекарственных препаратов растительного происхождения.

Ключевые слова: антимикробная активность; модификации метода диффузии в агар; антимикробная активность лекарственных препаратов растительного происхождения

Адреса для листування:

79010, м. Львів, вул. Пекарська, 69.

Тел. 093-382-60-40.

E-mail: vorobetsnatalia@gmail.com,

vorobets@meduniv.lviv.ua.

Львівський національний медичний університет

ім. Данила Галицького
Надійшла до редакції 10.02.2016 p. 